\title{
DA VINCULAÇÃO À LEI À VINCULAÇÃO AO DIREITO: \\ a juridicidade como paradigma
}

Matheus Teixeira da Silva ${ }^{1}$

\section{RESUMO}

O presente trabalho tem por escopo a discussão sobre a ruptura do paradigma da legalidade, superado pelo da juridicidade. Assim, analisam-se os fundamentos sobre os quais fundou-se a legalidade, bem como as razões pelas quais restou superada. Ainda, busca-se a conceituação da compreensão da juridicidade, traçando-se seus possíveis desdobramentos práticos.

PALAVRAS-CHAVE: Juridicidade. Legalidade. Sistema jurídico. Hermenêutica.

FROM THE LINKAGE TO RULES TO THE LINKAGE TO THE LAW:

the juridicity as paradigm

\begin{abstract}
This study has as scope the discussion about the rupture of the legality paradigm, overpassed by the juridicity one. Thus, we analyse the reasons upon wich the legality was founded, and also the reasons why it became surpassed. Still, seeks the understanding of the concept of juridicity, by drawing its possible practical consequences.
\end{abstract}

KEY-WORDS: Juridicity. Legality. Legal system. Hermeneutics.

\section{INTRODUÇÃO}

O presente trabalho tem por escopo a discussão sobre o desenvolvimento da compreensão do princípio da legalidade, próprio da tradição do Civil Law, o qual culmina na noção de juridicidade, operando-se, desta forma, uma alteração entre a vinculação jurídico-normativa do Estado: se outrora este tinha sua atuação vinculada diretamente à lei, hodiernamente tal vinculação amplia-se ao Direito, sistematicamente compreendido, ampliando-se, pois, a complexidade de tal vínculo.

Destarte, busca-se ao longo do texto a exposição dos fundamentos jurídico-dogmáticos que sustentam o princípio da juridicidade, avaliando-se pertinência de sua existência e a necessidade

\footnotetext{
1 Especialização em Direito Processual Civil pela Pontifícia Universidade Católica do Rio Grande do Sul, Brasil(2012)Advogado do Russowsky, Winter \& Guazzelli Peruchin Advogados Associados, Brasil Artigo recebido em: 08/01/2012 e aprovado em 30/04/2012
} 
Revista da Faculdade de Direito da UERJ,V.2, n.22,jul./dez.2012

Pági n a $\mid 2$

de sua adequada compreensão, na medida em que a atual noção de sistema jurídico não opera no mesmo diapasão da noção de legalidade estrita.

Nesse sentido, o trabalho está estruturado em dois blocos: o paradigma da legalidade e o paradigma da juridicidade; cada um dos blocos subdivide-se em outros dois, a fim de facilitar o fluxo textual, expondo-se os principais elementos configuradores dos princípios em análise.

A investigação tem como perspectiva a análise do fenômeno da juridicidade a partir da relação existente entre Administração Pública e o Direito, embora não se negue a possibilidade de ampliação da noção de juridicidade aos outros ramos do Direito.

Em síntese, a proposta argumentativa que permeia o texto é sintetizada por Pontes de Miranda, para quem "o Direito, e não a lei como texto, é o que se teme seja ofendido".

\section{O PARADIGMA DA LEGALIDADE}

Por razões históricas, o pensamento jurídico hodierno das comunidades do Civil Law vincula a atuação da Administração Pública (e do Poder Judiciário) à lei de maneira inextricável. Assim, os operadores jurídicos têm pouca margem de atuação e comprometida capacidade de análise das outras fontes do direito, já que têm na lei, em sentido estrito, a única fonte legítima do Direito.

Desta forma, analisar-se-á, na sequência, sob perspectiva histórica, as razões pelas quais formou-se e solidificou-se o entendimento segundo o qual a lei deve ser fonte e limite da atuação estatal, sem espaço para outros elementos normativos, submetendo-se, assim, o Estado à letra da lei, inexoravelmente.

\subsection{A SUBMISSÃO DO ESTADO À LEI}

A compreensão ora estudada de elevado prestígio da lei (em sentido estrito) ou de primazia da lei, tem origem no século XVIII, com as revoluções burguesas no continente europeu, as quais deram azo ao aparecimento de um novo modelo de estrutura organizacional do aparelho do Estado. O embrião ideológico, porém, havia surgido muito antes, com a promulgação da famosa Magna Carta de João Sem Terra, na Inglaterra em 1215, a qual limitava de certo modo o poder do Estado no tocante à exigibilidade tributária.

Nesse diapasão, o Estado Liberal (também denominado burguês), surgido em decorrência da necessidade de pôr-se termo à excessiva concentração e abuso de poder do período absolutista, e propugnado por conceituados autores, tais como Montesquieu, Rousseau, Locke, Kant, Hegel, 
Revista da Faculdade de Direito da UERJ,V.2, n.22,jul./dez.2012

Pági na $\mid 3$

Adam Smith, Madison, Bentham, Benjamin Constant, Tocqueville e Stuart Mill, teve como grande mérito a criação de mecanismos hábeis a reduzir e regular, juridicamente, o uso do poder advindo da atividade estatal, bem como assegurar as liberdades de ordem política e civil aos indivíduos. (Nesse sentido, MIRANDA, 2011, p. 36).

Assim, com a finalidade de criar e resguardar garantias aos cidadãos, os Estados Nacionais Modernos evoluíram rumo ao Estado Liberal, seja através do padrão britânico, isto é, através de uma evolução político-institucional, seja pelo modelo francês, qual seja, a ruptura revolucionária principiologicamente fundamentada - da ordem então constituída (SOUZA JUNIOR, 2002, p. 24).

Nesse sentido, o Estado Liberal possuía poucas mas bem definidas funções, constituídas, basicamente, da administração razoável da justiça, do poder de polícia e da proteção contra inimigos externos, configurando-se, assim, os elementos essenciais que consubstanciariam a defesa dos interesses imediatos dos cidadãos: liberdade, propriedade e segurança (SOUZA JUNIOR, 2002, p. 36).

Destarte, democraticamente, pela via legislativa, a lei assumiria elevada importância, pois seria assimilada como garantidora da manutenção da ordem alcançada e estabelecida, confundindo-se, assim, com a própria justiça. Como expõe Souza Junior, "no Estado Liberal a lei é expressão da justiça: é uma tradução positiva de leis naturais, anteriores e superiores ao Estado" (SOUZA JUNIOR, 2002, p. 48). Em consequência, ao Estado só seria permitido atuar no compasso da lei, inexistindo qualquer alternativa legítima a tal impositivo político-jurídicoinstitucional.

Deste modo, indo ao encontro dos elementos já expostos, a lição de Ferreira Filho é merecedora de registro:

À lei a cosmovisão liberal reserva um duplo papel. Se as Declarações se dirigem principalmente ao constituinte, se as Constituições organizam e restringem os poderes do Estado, as leis, por um lado, delimitam a liberdade dos indivíduos, enquanto, por outro lado, estabelecem a própria pauta de atuação dos órgãos estatais superiores. (FERREIRA FILHO, 2007, p. 19)

Desta forma, a lei assume dupla função, podendo ser compreendida como limite e também como fundamento da atividade estatal, estabelecendo, assim, uma vinculação negativa e outra positiva ao Estado em relação a ela, respectivamente. Nesse diapasão é o magistério de Canotilho:

A administração está vinculada à lei não apenas num sentido negativo (a administração pode fazer não apenas aquilo que a lei 
expressamente autorize, mas tudo aquilo que a lei não proíbe), mas num sentido positivo, pois a administração só pode actuar com base na lei, não havendo qualquer espaço livre da lei onde a administração possa actuar como um poder jurídico livre. (CANOTILHO, 2003, p. 833)

Dado o nível de importância reconhecido à lei, exsurge, pois, de maneira natural, o princípio da legalidade, mencionado em O Espírito das Leis de Montesquieu, para quem "numa sociedade onde há leis, a liberdade só pode consistir em poder fazer o que se deve querer, e em não ser obrigado a fazer o que não se deve querer." O autor prossegue: “A liberdade é o direito de fazer tudo o que as leis permitem" (MONTESQUIEU, 2004, p. 167).

O princípio da legalidade, "fruto da submissão do Estado à Lei” (BANDEIRA DE MELLO, 2005, p. 91), em consonância ao ideário liberal, como visto, "põe como regra a liberdade, como exceção, a restrição" (FERREIRA FILHO, 2007, p. 23), assumindo, assim, papel de extrema relevância no constitucionalismo, firmando-se nos contextos político-jurídicos até os dias atuais.

A lição de Pimenta Bueno vai ao encontro do pensamento traçado:

A liberdade não é pois exceção, é sim a regra geral, o princípio absoluto, o direito positivo; a proibição, a restrição, isso sim é que são as exceções, e que por isso mesmo precisam ser provadas, achar-se expressamente pronunciadas pela lei, e não por modo duvidoso, sim formal, positivo; tudo o mais é sofisma. (BUENO, 1987, p. 382)

Para o publicista português Paulo Otero, a legalidade funda-se - na esteira do pensamento de Montesquieu - sobre três ideias nucleares: (i) a lei passa a ser compreendida como expressão racional emanada da vontade geral; (ii) o poder encontraria na lei um critério para suas decisões e (iii) a lei assumiria uma função garantidora das liberdades. (OTERO, 2011, p. 51)

Ainda consoante o publicista português:

A lei traduzia, segundo os postulados liberais, um produto da razão, revelação de uma verdade absoluta pelos mais idôneos representantes da sociedade, encontrando-se apta a regular todas as matérias sobre as quais um Estado mínimo sentia necessidade de intervir, assumindo a natureza de instrumento de garantia do cidadão perante o poder e possuindo ainda, nos termos de uma 
concepção positivista-legalista do Direito, o estatuto de primeira e mais importante fonte de Direito. (OTERO, 2011, p. 153)

José Afonso da Silva, a seu turno, comenta o princípio da legalidade insculpido na Constituição brasileira de 1988, compreendido por este como "submissão e respeito à lei":

O princípio da legalidade é nota essencial do Estado de Direito. É também, por conseguinte, um princípio basilar do Estado Democrático de Direito, porquanto é da essência do seu conceito subordinar-se à Constituição e fundar-se na legalidade democrática. (...) Toda sua atividade fica sujeita "à lei”, entendida como expressão da vontade geral, que só se materializa num regime de divisão de Poderes em que ela seja o ato formalmente criado pelos órgãos de representação popular, de acordo com o processo legislativo estabelecido na Constituição. É nesse sentido que se deve entender a assertiva de que o Estado, ou o Poder Público, ou os administradores não podem exigir qualquer ação, nem impor qualquer abstenção, nem tampouco mandar proibir coisa alguma aos administrados, senão em virtude de lei. (SILVA, 2009, p. 82)

Assim, como evolução natural das sociedades e dos modelos jurídicos, a legalidade fez-se presente para garantir a preservação de direitos e para melhor coordenar a atuação estatal, constituindo-se, pois, em importantíssima conquista histórica do Direito. Maria Sylvia Zanella Di Pietro chega a firmar, sem exagero, que o princípio da legalidade "constitui uma das principais garantias de respeito aos direitos individuais" (DI PIETRO, 2007, p. 58).

De forma quiçá hiperbólica, Bandeira de Mello assim explica o princípio da legalidade no ordenamento pátrio:

O princípio da legalidade é o da completa submissão da Administração às leis. Esta deve tão-somente obedecê-las, cumpri-las, pô-las em prática. Daí que a atividade de todos os seus agentes, desde o que lhe ocupa a cúspide, isto é, o Presidente da República, até o mais modesto dos servidores, só pode ser a de dóceis, reverentes, obsequiosos cumpridores das disposições gerais fixadas pelo Poder Legislativo, pois esta é a posição que lhes compete no Direito brasileiro. (BANDEIRA DE MELO, 2005, p. 92) 
Revista da Faculdade de Direito da UERJ,V.2, n.22,jul./dez.2012

Pági na $\mid 6$

Não por outro motivo a Constituição Federal de 1988 insculpiu o princípio da legalidade no título dedicado aos direitos e garantias fundamentais, ao normatizar no inciso II do art. $5^{\circ}$ que "ninguém será obrigado a fazer ou deixar de fazer alguma coisa senão em virtude de lei”.

Todavia, em que pesem as relevantes contribuições das diferentes noções da legalidade trazidas pelo Estado Liberal, as quais tiveram papel importante para o desenvolvimento dos modelos de atividade dos Estados ocidentais, constituindo-se a legalidade um elemento essencial à noção de Estado de Direito, pode-se questionar a adequação metodológica do uso de critérios estritamente legais - e portanto formais - para aferição da conformidade de determinado elemento fático ou jurídico com o Direito, na medida em que a noção de sistema jurídico sustentada hoje pela ciência jurídica difere da compreensão de outrora.

\section{2 (IN)SUFICIÊNCIA EPISTEMOLÓGICA DA LEGALIDADE}

Diversas modificações ocorrerem ao longo dos séculos acerca da compreensão da fenomenologia jurídica. Assim, faz-se imperioso o apontamento da concepção contemporânea do conceito de sistema jurídico, pois é a partir de tal premissa que se estudará a (in)suficiência da legalidade enquanto parâmetro de verificabilidade da eventual conformidade ao Direito de qualquer objeto que se pretenda analisar, seja este norma ou fato. ${ }^{2}$ Em outras palavras, busca-se "refletir sobre a veracidade de certos dogmas clássicos relativos à legalidade administrativa que se vão transmitindo de modo mecânico aos juristas de geração em geração" (OTERO, 2011, p. 19).

Desta forma, urge, portanto, a necessidade de assimilar-se que "o sistema jurídico é uma rede aberta, tópica e axiologicamente hierarquizada de regras, princípios e valores" (ARONNE, 2001, p. 55) que não se pode operar através de metodologias formalistas; não se pode olvidar que a busca pela "racionalidade das "verdades claras e distintas", própria das ciências demonstrativas, é "uma ridícula demonstração de anacronismo epistemológico" (SILVA, 2006, p. 69), na medida em que, como já apontou Canaris, "as dificuldades próprias do pensamento jurídico não se deixam transpor com os meios da lógica formal" (CANARIS, 2008, p. 70), com a qual guarda estreita relação a legalidade. O Direito, não custa lembrar, não se pode operar através de silogismos.

A fim de proceder-se à análise dos elementos caracterizadores do sistema jurídico, faz-se necessária, de plano, a apreciação da obra de Canaris.

Defende o professor Canaris a necessidade de inserção dos princípios na rede normativa a fim de conferir-lhe uma "função aglutinadora" (CANARIS, 2008, p. 81), na medida em que esta não 
Revista da Faculdade de Direito da UERJ,V.2, n.22,jul./dez.2012

poderia ser composta apenas por regras (em sentido estrito). Assim, destaca que "os princípios não valem sem exceção e podem entrar entre si em oposição ou em contradição; eles não têm a pretensão da exclusividade; eles ostentam o seu sentido próprio apenas numa combinação de complementação e restrição recíprocas (...)" (CANARIS, 2008, p. 88).

As vantagens de tal compreensão são demostradas pelo próprio autor, ao tecer suas observações sobre a eterna dicotomia entre justiça e segurança jurídica:

O sistema móvel representa um compromisso particularmente feliz entre os diversos postulados da ideia de Direito - e também a segurança jurídica sempre é garantida em maior medida do que perante uma mera cláusula de equidade - e equilibra a 'polaridade' deles numa solução ponderada e 'intermédia'; tanto se afasta do rigorismo das normas rígidas como da ausência de contornos da pura cláusula de equidade. (CANARIS, 2008, p. 145)

Assim, propõe Canaris uma compreensão sistemática do Direito, através da qual seja possível deixar-se de buscar a ratio legis para buscar-se a ratio juris (CANARIS, 2008, p. 159): a diferença entre os dois objetos é abissal, representando uma ruptura ideológica atrav's da inserção do elemento teleológico no raciocínio jurídico, sedimentando-se, assim, a ideia de que a ciência do direito é hermenêutica (CANARIS, 2008, p. 266) e não se dissocia das questões axiológicas.

No mesmo sentido, a obra de Juarez Freitas propõe a apreensão do sistema jurídico, “inacabado e inacabável” (FREITAS, 2004, p. 47), como rede hierarquizada de princípios, regras e valores, demonstrando o anacronismo dos raciocínios subsuntivos ante a inclusão da dimensão axiológica no Direito:

Com efeito, improdutivo se revela qualquer critério de subsunção mecânica assim como o dogma da automática vinculatividade das normas jurídicas (princípios ou regras), pois uma abordagem estrita - situada no plano silogístico-formal ou baseada na autoridade de quem estatuiu os comandos normativos - esbarra nas necessárias considerações acerca da mínima legitimidade e da nuclear correção valorativa do ordenamento. (FREITAS, 2004, p. 26) (sem grifos no original)

Ainda, sustenta o autor, em consonância aos ensinamentos de Canaris, que "o Direito Positivo é aberto, vale dizer, a ideia de um suposto conjunto autossuficiente de normas não apresenta a menor plausibilidade, seja no plano teórico, seja no plano empírico" (FREITAS, 2004, p. 32). 
Revista da Faculdade de Direito da UERJ,V.2, n.22,jul./dez.2012

Pági na $\mid 8$

Destarte, afirma que "a validade do sistema jurídico (...) funda-se, em última instância, sobre valores, mostrando-se inegável a concorrência de múltiplos elementos axiológicos em todas as construções jurisprudenciais, justificando-se a multiplicidade como sinal de pluralismo democrático" (FREITAS, 2004, p. 38). Afirma, ainda, que "o sistema não se constrói dotado de estreitos e definitivos contornos, máxime porque o dogma da completude não resiste à constatação de que as contradições e as lacunas acompanham as normas, à feição de sombras irremovíveis" (FREITAS, 2004, p. 39).

Para Juarez Freitas o sistema jurídico é, pois:

(...) uma rede axiológica e hierarquizada topicamente de princípios fundamentais, de normas estritas (ou regras) e de valores jurídicos cuja função é a de, evitando ou superando antinomias em sentido lato, dar cumprimento aos objetivos justificadores do Estado Democrático, assim como se encontram consubstanciados, expressa ou implicitamente, na Constituição. (FREITAS, 2004, p. 54) (sem grifos no original)

Observa-se que a semelhante conclusão chegou Ricardo Aronne, para quem o sistema é "previsível em sua dinâmica caótica” (ARONNE, 2010, p. 69):

O sistema jurídico é uma rede móvel, entrópica, aberta e axiologicamente hierarquizável de regras, princípios e valores, positivados no ordenamento de modo implícito ou explícito, teleologicamente orientados na concretização tópica. O sistema é sensível às condições iniciais que lhe são propostas, é não linear, respondendo diferente e não proporcionalmente a 'inputs' ou interações diferentes. Decorrência, ainda, de sua abertura, é sua complexidade de arquiteturas e influências a que, necessária e corretamente, se expõe. (ARONNE, 2010, p. 204) (sem grifos no original)

Não distoa dos elementos já expostos a lição de Canotilho: para o constitucionalista português, o sistema jurídico é um "sistema normativo aberto de regras e princípios":

(1) é um sistema jurídico porque é um sistema dinâmico de normas; (2) é um sistema aberto porque tem uma estrutura dialógica (Caliess), traduzida na disponibilidade e 'capacidade de aprendizagem' das normas constitucionais para captarem a mudança da realidade e estarem abertas às concepções cambiantes da 'verdade' e da 'justiça'; (3) é um sistema normativo, porque a 
estruturação das expectativas referentes a valores, programas, funções e pessoas, é feita através de normas; (4) é um sistema de regras e princípios, pois as normas do sistema tanto podem revelar-se sob a forma de princípios como sob a sua forma de regras. (CANOTILHO, 2003, p. 1159)

Desta forma, tem-se de apreender o sentido contemporâneo de sistema jurídico, deixando de lado as pretensões de outrora, através das quais almejava-se um sistema fechado, completo e composto apenas por regras, sem conexão com o mundo real, tampouco compromissado com os ideais de ética e de justiça. O Direito é muito mais que a lei, e tal já foi demonstrado por Chaïm Perelman, que sentenciou:

Os fatos que sucederam na Alemanha, depois de 1933, demonstraram que é impossível identificar o direito com a lei, pois há princípios que, mesmo não sendo objeto de uma legislação expressa, impõem-se a todos aqueles para quem o direito é a expressão não só da vontade do legislador, mas dos valores que este tem por missão promover, dentre os quais figura em primeiro plano a justiça. (PERELMAN, 2004, p. 95)

A afirmação citada justifica-se porque, pelo paradigma da legalidade, o que está em conformidade à lei está correto, necessariamente. O magistério de Ferreira Filho é no sentido de que "a legalidade se desvincula da justiça" (FERREIRA FILHO, 2007, p. 51), na medida em que, como visto, pelo paradigma da legalidade, não há espaço para análise da justeza dos atos estatais, mas tão somente para os silogismos formais através dos quais perquire-se tão-somente a existência de subsunção possível entre o ato e o texto legal.

Evidentemente que tal vínculo estabelecido pelo Estado Liberal (e portanto pela legalidade também) entre cumprimento da regra e adequação jurídica não possui relação lógica alguma, senão, mera presunção de legitimidade, sob pena de se convalidar a lamentável afirmação de H. Kelsen segundo a qual, "do ponto de vista da ciência do Direito, o direito editado pelo governo nazista era direito" (in FERREIRA FILHO, 2007, p. 45).

Parece clara a ideia de que o Direito é superior à lei - razão pela qual a falácia kelseniana não pode ser tolerada - e motivo também pelo qual configura-se a insuficiência do princípio da legalidade para dar conta da complexidade jurídica do mundo atual, no qual o Direito existe enquanto sistema de múltiplas fontes e valores, e não enquanto mero conjunto de regras em 
Revista da Faculdade de Direito da UERJ,V.2, n.22,jul./dez.2012

Pá g in a 10

sentido estrito; a legalidade, enquanto princípio de subserviência estrita à lei, não se coaduna com a noção de sistema.

Transcreve-se, como síntese, a lição de Paulo Otero, pela pertinência:

As ideias de primado do parlamento e de divinização da lei, seja como expressão da vontade geral ou como instrumento garantístico da igualdade de todos os cidadãos, permitem alicerçar durante o século XIX uma concepção positivista que, configurando a lei como principal fonte de Direito e fazendo da codificação a bandeira da cientificidade e da modernidade dos ordenamentos jurídicos, reconduzem todo o Direito ao Estado: a legalidade administrativa é, nesse preciso contexto, expressão da estadualidade de toda a ordem jurídica.

Sucede, porém, que este cenário tipicamente oitocentista de estadualidade das fontes de Direito se encontra hoje substancialmente alterado por um fenômeno de descentramento estadual da legalidade: a concepção monista do Direito está substituída por uma concepção de pluralismo jurídico. (...)

A legalidade administrativa passa a integrar-se no contexto de um sistema policêntrico de fontes de Direito. (OTERO, 2011, p. 148)

\section{O PARADIGMA DA JURIDICIDADE}

Desde que pessoas evitem a leviandade ou o capricho, e observem uma constância decente de julgamento ao longo do tempo, além de permanecerem abertos a rever suas opiniões à luz de argumentos bem fundamentados, elas não são irrazoáveis apenas porque adotam uma visão diferente da minha ou da sua. Neil MacCormick

Ante a inexorável necessidade de compreensão do direito enquanto sistema composto por um conjunto amplo de normas provenientes de múltiplos diplomas - bem como valores - por vezes caoticamente ordenadas, sempre em busca de um telos, isto é, uma ratio, urge o estudo e a compreensão da proposta dogmática da juridicidade, compreendida como superação da legalidade estrita, em consonância à ideia de que "o princípio da legalidade não pode ser compreendido de maneira acanhada" (FIGUEIREDO, 2003, p. 42), mas sim no "contexto sistemático". (FIGUEIREDO, 2003, p. 45)

Proceder-se-á, assim, à análise dogmática do conteúdo da juridicidade e seus possíveis desdobramentos práticos. 


\subsection{JURIDICIDADE: FUNDAMENTOS E TENTATIVA CONCEITUAL}

A juridicidade pode ser compreendida como a adequação do princípio da legalidade à atual estrutura complexa e sistemática do Direito, não mais identificada com apenas uma fração da estrutura jurídico-normativa, ou seja, as regras. Como expõe Lúcia Valle Figueiredo, o administrador necessariamente "deve estar submetido também ao Direito" (FIGUEIREDO, 2003, p. 42), sendo este, evidentemente, muito mais abrangente e complexo do que a simples (senão simplória) noção de legalidade. Nas palavras de Binenbojm, "a vinculação da Administração não se circunscreve, portanto, à lei formal, mas a esse bloco de legalidade (o ordenamento jurídico como um todo sistêmico)." (BINENBOJM, 2008, p. 141.)

Não se defende, todavia, a destruição do princípio da legalidade, mas sim a construção de uma nova compreensão a partir da qual seja possível atender à demanda pelo respeito às regras (corolário do princípio da segurança jurídica, essencial a um Estado de Direito) e também pelo respeito ao sistema - complexamente estruturado e não restrito à normatividade única das regras -, já que, na lição de Juarez Freitas, "o conteúdo jurídico, por força da natureza valorativa, transcende o mera e esparsamente positivado" (FREITAS, 2009, p. 71), sobretudo nos chamados hard cases, acrescenta-se.

Nesse sentido, a síntese de Raimundo Parente sobre a juridicidade merece registro:

Em virtude dos fenômenos da principialização e da constitucionalização do Direito, não mais se justifica explicar as relações da Administração Pública com o ordenamento jurídico à luz da ideia de vinculação positiva à lei. É que a vinculação da Administração ao ordenamento jurídico não se restringe somente à lei formal e à regra legal veiculada, mas à totalidade sistêmica do ordenamento jurídico que se manifesta na unidade de sentido normativo. (ALBUQUERQUE JÚNIOR, 2010, p. 199)

Com efeito, evidencia-se o descompasso existente na extremada valoração da legalidade quando esta sobrepõe-se aos demais princípios e valores do sistema jurídico; em contrapartida, não se pode tolerar que a flexibilização, ou mesmo a ponderação do conteúdo normativo do princípio da legalidade, em cotejo com os demais elementos normativos, permita que se legitime o decisionismo fundado em critérios subjetivistas e ajurídicos. Como analisa Juarez Freitas: 
Se é inadmissível a crença de que o intérprete tenha de descobrir a intenção do legislador ou da lei, sem margem de apreciação justa ou proporcional, também é certo que não se devem quebrar as regras legais, abrindo exceções injustificáveis. (FREITAS, 2009, p. 71)

No mesmo sentido, a lição de Manuel Atienza:

O raciocínio jurídico não é nem 'uma simples dedução silogística' e nem, tampouco, 'a mera busca de uma solução eqüitativa', mas sim a 'busca de uma síntese na qual se leve em conta, ao mesmo tempo, o valor da solução e a sua conformidade com o Direito. $\mathrm{Ou}$, dito de outra forma, a conciliação dos valores de equiidade e segurança jurídica, a procura de uma solução que seja "não apenas de acordo com a lei como também eqüitativa, razoável e aceitável'. (ATIENZA, 2006, p. 77) (sem grifos no original)

Destarte, funda-se o princípio da juridicidade, enquanto superação da noção de legalidade estrita, em alguns pilares básicos, dentre os quais destacam-se, além da compreensão sistêmica do direito, já analisada no tópico 1.2, as ideias de (a) imperfeição da lei, (b) constitucionalização do direito, (c) principialização normativa, e (d) normatividade suprapositiva. Na sequência, analisarse-ão brevemente tais fenômenos.

\section{A) Imperfeição da lei}

A lei, porque expressada através da linguagem, torna-se imperfeita; nem poderia ser diferente, uma vez que a língua é instrumento inexato e falho.

Conforme Humberto Ávila, "toda norma, porque veiculada por meio da linguagem, é, em alguma medida, indeterminada" (ÁVILA, 2009, p. 85); para Herbert Hart, de mesma forma, "todas as regras têm uma penumbra de incerteza", ${ }^{3}$ bem como uma "textura aberta" (HART, 2007, p. 16). Clarice Beatriz da Costa Söhngen, remetendo à obra de Saussure, assevera a seu turno que “a língua é uma realidade falha, em que o equívoco não cessa de aparecer". (SÖHNGEN, 2006)

Resta evidenciado, assim, que a intrínseca natureza linguística das normas lhes confere uma dimensão intangível em razão da própria essência da linguagem: mostra-se totalmente descabida a pretensão de ver a norma como incontestável e não-interpretável; a complexidade da linguagem torna necessária - e por vezes tormentosa - a tarefa hermenêutica. 
Revista da Faculdade de Direito da UERJ,V.2, n.22,jul./dez.2012

Pág in a | 13

Não se pode pretender, pois, atrelar o operador do direito à letra da lei de forma inexorável, já que a falha da linguagem poderia conduzir a um erro material quando da aplicação do dispositivo legal, fulminando a justeza de tal elemento normativo quando de sua aplicação.

Outrossim, para além das questões linguísticas, a lei é produzida para regular os casos normais, isto é, os casos padrões, não sendo desarrazoado pretender-se negar aplicação à lei quando esta flagrantemente não se coadunar com o sistema, ainda que o fato seja subsumível ao texto legal. Consoante Castanheira Neves:

(...) em virtude de serem as normas prescritas na previsão apenas das hipóteses mais frequentes, comuns ou típicas dos casos que se propõem regular (...) não fica excluída a possibilidade de se decidir concretamente da sua aplicabilidade em termos diversos daqueles que imediatamente imporia o sentido significativo e conceitual (ou interpretável em abstracto) das normas, já aplicando-as a situações e casos formalmente abrangidos por ele. Situações e casos esses não-comuns ou atípicos relativamente às hipóteses determinantes das normas, e cuja atipicidade concreta justamente justifica aqueles desvios. (NEVES, 1993, p. 171)

\section{B) Constitucionalização do direito}

A expressão "constitucionalização do direito" ora empregada diz respeito à "impregnação" da normatividade constitucional no ordenamento jurídico, sobretudo na adaptação da normatividade infraconstitucional às exigências e aos postulados da Constituição, mormente no tocante aos elementos axiológicos existentes na Carta.

Consoante Binenbojm, "a nova principiologia constitucional (...) passa também a ocupar posição central na constituição de um direito administrativo democrático e comprometido com a realização dos direitos do homem”. (BINENBOJM, 2008, p. 142)

Assim, a validade das leis (em sentido lato) resta vinculada à conformidade constitucional existente, na medida em que a Constituição, capaz de irradiar sua força normativa para todo o ordenamento jurídico, sobretudo através de seus princípios, (BARROSO, 2010, p. 158) impõe uma certa uniformidade interpretativa, a qual deve ser com ela (Constituição) condizente.

Como observado por Otero, "as normas constitucionais em causa surgem como critério orientador imediato da interpretação, integração e aplicação de todos os atos infraconstitucionais" (OTERO, 2011, p. 741), evidenciando-se, além da relevância, a necessidade da normatividade constitucional para a atuação estatal. 
Revista da Faculdade de Direito da UERJ,V.2, n.22,jul./dez.2012

P á g i n a | 14

Nesse diapasão, em ensaio dedicado ao assunto, Luís Roberto Barroso tece o raciocínio apto a apontar a relação direta entre o fenômeno da constitucionalização do direito ao fenômeno da juridicidade:

Supera-se, aqui, a idéia restrita de vinculac $\square$ ão positiva do administrador à lei, na leitura convencional do princípio da legalidade, pela qual sua atuac $\square$ ão estava pautada por aquilo que o legislador determinasse ou autorizasse. $\mathrm{O}$ administrador pode $\mathrm{e}$ deve atuar tendo por fundamento direto a Constituic $\square \tilde{a}$ o e independentemente, em muitos casos, de qualquer manifestac $\square$ ão do legislador ordinário. O princípio da legalidade transmudase, assim, em princípio da constitucionalidade ou, talvez mais propriamente, em princípio da juridicidade, compreendendo sua subordinac $\square$ ão à Constituic $\square$ ão e à lei, nessa ordem. (BARROSO, 2007, p. 30) (sem grifo no original)

\section{C) Principialização normativa}

Cretella Jr. leciona que princípio é "toda proposição, pressuposto de um sistema, que lhe garante a validade, legitimando-o". Para o autor, os princípios podem ser compreendidos como "a premissa primeira do sistema”. (CRETELLA JÚNIOR, 2000, p. 06) Ainda sobre as características dos princípios, Humberto Ávila:

Como os princípios se constituem em normas imediatamente finalísticas e mediatamente de conduta, a justificativa da decisão de interpretação será feita mediante avaliação dos efeitos da conduta havida como meio necessário à promoção de um estado de coisas posto pela norma como ideal a ser atingido. (ÁVILA, 2009, p. 75)

Importa ressaltar que os princípios, diferentemente das regras (GRAU, 2006, p. 49), têm convivência não-antinômica, mesmo quando em sentido contrário. Explica-se:

Diversamente das regras, que convivem no plano da validade, em face de sua concreticidade, reduzindo a discricionariedae do intérprete, os princípios convivem no plano valorativo. São dialógicos. Suas razões são complementares, mesmo no antagonismo. 
As regras têm um convívio antinômico, dialético, afastando-se no caso de antinomia para valer ou não, topicamente. Os princípios não. De convivência conflitual, hierarquizam-se axiologicamente para preservar a unidade material do sistema. Dialogam. Relativizam-se mutuamente na incidência tópica, no encadeamento teleológico dos valores em destaque. (ARONNE, 2010, p. 72)

Destarte, à luz de tais ponderações, percebe-se a relevância da compreensão ampla e sistemática do Direito, a partir da qual a principiologia normativa permite a busca concomitante da segurança jurídica e da justiça material, minimizando-se, ao máximo o uso de subjetivismos, pois os princípios, em sendo normas, vinculam o operador.

Em outras palavras, como sustenta Paulo Otero, o arcabouço principiológico do ordenamento (por ele denominado "normatividade "principialista") funciona como "elemento aglutinador" (OTERO, 2011, p. 166) do sistema. Outrossim, mostra-se relevante a função oxigenadora realizada pelos princípios insertos no sistema; nas palavras de Aronne, "os princípios abrem as portas da manutenção do sistema, atualizando-o pela respiração axiológica condizente com a atualidade do ordenamento contemporâneo e as necessidades da sociedade destinatárias". (ARONNE, 2001, p. 267)

Em suma, como expõe Otero:

Um sistema tendencialmente fechado de legalidade é substituído por um sistema predominantemente aberto: a legalidade administrativa, à semelhança do que sucede com o sistema constitucional, torna-se predominantemente principialista (...). (OTERO, 2011, p. 167)

D) Normatividade suprapositiva

A concepção positivista do Direito, desde as atrocidades cometidas pelos regimes totalitários do século passado, não pode ser aceita, sob pena de se chancelarem juridicamente tais aberrações, as quais, ironicamente, tinham suporte institucional do próprio Direito. Como afirma Barroso, "o Direito, a partir da segunda metade do século XX já não cabia no positivismo jurídico”. (BARROSO, 2010, p. 327) 
Ciente de tal condição, em capítulo intitulado "o mito da onipotência do Direito escrito", Otero explora a existência de uma ordem axiológica suprapositiva, compreendida esta como a “consciência jurídica geral”. (OTERO, 2011, p. 411) Destarte, sustenta o jurista português:

O Direito positivo escrito - assuma ele uma dimensão constitucional ou meramente infraconstitucional - nunca pode esquecer ou ignorar uma ordem axiológica suprapositiva que, sendo independente de qualquer consagração positiva, funciona, todavia, como critério último de fundamento e de validade de toda a ordem jurídica que não se mostra axiologicamente neutra em termos de justiça. (OTERO, 2011, p. 411) (sem grifos no original)

Gize-se que, consoante o magistério de Otero, a submissão à "consciência jurídica geral” é devida não apenas pelas normas infraconstitucionais, mas também pela própria Constituição.

Assim, considerando que "o homem surge como autor e destinatário do Direito, radicando na sua dignidade o fundamento último de uma ordem jurídica axiologicamente justa" (OTERO, 2011, p. 415), Otero elenca alguns postulados estruturantes da ideia de uma "consciência jurídica geral": (a) o dever de proteção à vida humana; (b) a interdição da utilização do ser humano como meio; (c) o pleno desenvolvimento da personalidade, com o reconhecimento dos direitos a ela inerentes; (d) a interdição do arbítrio e das discriminações infundadas; (e) o direito de recusa ao cometimento de uma injustiça.

Desta forma, pode-se observar que, por ter a "consciência jurídica geral" uma materialidade inexoravelmente conexa à dignidade humana enquanto direito fundamental, não pode ser ditada pela maioria de plantão; do contrário, as maiorias políticas estariam legitimadas a oprimir as minorias, tolhendo-lhes direitos fundamentais. A configuração da "consciência jurídica geral", portanto, independe da "vontade geral".

Como depreende-se, a noção de uma normatividade suprapositiva protetora de um núcleo básico e fundamental de direitos inerentes à condição humana, apresenta-se como parâmetro configurador da juridicidade, enquanto (i) limitador de afrontas a preceitos fundamentais e (ii) garantidor de tais direitos, independentemente de positivação.

Em síntese, a análise dos elementos expostos permite concluir-se que "a pluralidade de fontes normativas legitimadas passa a exigir um conceito mais amplo [de legalidade], qual seja, o da juridicidade”. (MOREIRA NETO, 2005, p. 104) 


\subsection{A JURIDICIDADE E SEUS POSSÍVEIS DESDOBRAMENTOS PRÁTICOS}

A compreensão ora proposta de juridicidade permite que se tracem alguns desdobramentos possíveis que exsurgem a partir da concepção trabalhada. Assim, serão explicitadas possíveis consequências do fenômeno da juridicidade, de forma meramente ilustrativa, pois, evidentemente, não seria possível sequer almejar-se exaurir a matéria, a qual é inesgotável. Ademais, o presente tópico tem por escopo a reunião de elementos exemplificativos de desdobramentos da juridicidade, e não a análise minuciosa de cada um deles.

(A) Juridificação de elementos fáticos

A partir da noção de juridicidade apontada, verifica-se a possibilidade de juridificação de fatos não formalizados, isto é, a atribuição de valoração jurídica a fatos que, a priori, não poderiam ser reconhecidos juridicamente. Em outras palavras, é dizer que a juridicidade pode conferir relevância jurídica à mera existência fática de determinadas situações, algo inimaginável sob o prisma legalista.

Nesse diapasão, Otero exemplifica a juridificação de fatos à luz de três situações possíveis: (i) o costume administrativo, (ii) as praxes, práticas e usos administrativos e (iii) o precedente administrativo. (OTERO, 2011, p. 1084)

Tais fatos, praticados pela própria Administração, tem o poder de "subverter" a legalidade e a dicotomia entre validade e invalidade, (OTERO, 2011, p. 783) pois mesmo não sendo tais atos formais sob a perspectiva estrita da legalidade (razão pela qual seriam ilícitos e inválidos pelo paradigma da legalidade), são merecedores de consideração pela simples existência, a qual é capaz de lhes conferir validade jurídica, a despeito da ilegalidade formal.

Ressalte-se, ainda, que o reconhecimento de tais atos ou precedentes da Administração têm força jurídica para normatizar ou até mesmo vincular a própria Administração, que não poderá alegar a ilegalidade da sua própria conduta, salvo, evidentemente, as hipóteses em que houver argumentos - de interesse público - suficientes para desconsideração de tal situação, à luz de uma análise sistemática. Tal compreensão tem por fundamento, como expõe Otero, (OTERO, 2011, p. 786) a proibição de venire contra factum proprium, bem como a própria segurança jurídica

(B) Consolidação temporal de situações jurídicas viciadas 
Revista da Faculdade de Direito da UERJ,V.2, n.22,jul./dez.2012

Pág in a | 18

É consabido que os atos jurídicos viciados podem sofrer consequências ulteriores aptas a os tornarem sem nenhum valor jurídico: o sistema normativo permite que determinados vícios tornem os atos imperfeitos anuláveis, uma vez que, desrespeitadas determinadas formalidades, o ato estaria em desconformidade à estrutura jurídica de regência, razão pela qual configurar-se-ia a ilegalidade.

Entretanto, outros fatores devem ser analisados, em cotejo à legalidade estrita do ato. Ocorre que a existência de princípios tais como a segurança jurídica e a boa-fé podem levar a conclusão diversa.

Nesse diapasão, Otero (OTERO, 2011, p. 1026) sustenta que o decurso do tempo poderia consolidar a situação jurídica viciada, convalidando-a. Isto porque deve-se ponderar se a anulação do ato, por sua desconformidade à lei (em sentido amplo), não estaria gerando uma ofensa ao sistema ainda maior do que a sua manutenção, ainda que tal ato esteja impregnado de vícios: ocorre que o reconhecimento do vício com a consequente anulação poderia fulminar a segurança jurídica e a boa-fé existentes. Assim, evidencia-se a necessidade de um cotejo entre os valores tutelados pelo sistema jurídico, já que, de um lado encontra-se a necessidade de obediência às regras vigentes e de outro a proteção da segurança jurídica e a boa-fé, razão pela qual tais conflitos apenas podem ser resolvidos topicamente, jamais em abstrato.

Ciente de que tal proposição de convalidação de atos viciados pelo tempo produz grande desconforto, o publicista português (OTERO, 2011, p. 1027) faz comparação irrespondível, na medida em que, conforme expõe o autor, da mesma forma que o ato administrativo viciado poderia produzir efeitos, nenhum jurista duvida do fato de que a sentença judicial viciada transitada em julgado, ainda que por vício de inconstitucionalidade, produz efeitos, operando-se uma espécie de convalidação do vício também pelo trânsito em julgado judicial. Haveria, pois, entre as jurisdicionais e administrativas, tal possibilidade.

Otero leva o raciocínio às últimas consequências, chegando a sustentar que até mesmo aos atos inexistentes podem ser atribuídos efeitos jurídicos:

Também à luz de atos feridos de inexistência se podem edificar situações de fato que, (...) o decurso do tempo pode, atendendo a razões de segurança, certeza, estabilidade e confiança, justificar que se atribuam efeitos jurídicos. (OTERO, 2011, p. 1027)

(C) Nulificação de situação jurídica por afronta a direito fundamental 
Revista da Faculdade de Direito da UERJ,V.2, n.22,jul./dez.2012

Pág in a | 19

Se por um lado admite-se a convalidação de um ato que esteja em desconformidade a determinado preceito legal a fim de resguardar princípios de elevado prestígio pelo sistema, como visto, por outro lado não se admite a existência de atos jurídicos que se mostrem capazes de provocar lesões a direitos fundamentais.

O mesmo raciocínio que leva à conclusão pela manutenção no sistema do ato formalmente ilegal, em homenagem à segurança, à boa-fé etc., conduz também à conclusão segundo a qual eventual ato que, mesmo respeitando os preceitos formais infraconstitucionais, caso fulmine algum direito fundamental, deverá ser nulificado: trata-se do reconhecimento da importância nuclear desempenhada pelos direitos fundamentais, os quais jamais poderão sofrer qualquer espécie de desconsideração.

Com autoridade, Otero explica a questão:

A violação administrativa do conteúdo essencial de um direito fundamental acarreta sempre a nulidade dos respectivos atos jurídicos, expressando uma manifestação da especial vinculatividade direta e imediata dos órgãos administrativos às normas sobre direitos fundamentais. (OTERO, 2011, p. 741)

Evidencia-se, pois, a necessidade constante de reverência aos direitos fundamentais, compreendendo-se que "o princípio da justiça e a `ideia de Direito` decorrentes do respeito pela dignidade da pessoa humana, [atuam] funcionando como alicerces últimos da adequação valorativa e da unidade do Direito". (OTERO, 2011, p. 333)

(D) Inaplicabilidade de regras injustas

A apreensão do sentido amplo da juridicidade, para além do raciocínio legalista e silogístico, permite o questionamento sobre a (in)aplicabilidade de regras manifestamente injustas ao caso que se analise, ainda que haja possibilidade se subsunção formal.

Em outras palavras, pode-se dizer que a finalidade do reconhecimento da possibilidade de não-aplicação de determinada regra é a de evitar o cometimento de injustiças no momento de aplicação da norma, na medida em que, em algumas situações, ainda que aparentemente a norma seja "subsumível”, existem fatos (exceções) que tornam a aplicação indevida.

Como asseverou Gerson Godinho da Costa, em dissertação:

A identificação do Direito com a lei gerou dois problemas graves. Um relacionado à ausência da inalcançável racionalidade da 
legislação, o outro, que lhe é decorrente, atinente à flagrante e indiscutível injustiça pela aplicação automática de algumas regras jurídicas. (COSTA, 2008, p. 59)

O que se afirma é que, em algumas circunstâncias, a mera subsunção não é apta a aferir a adequabilidade da norma jurídica ao caso concreto. Isto porque, como explica Castanheira Neves, a norma, para ser aplicada, há de ter sido elaborada com a intenção de ser utilizada em um caso como o que se examine. Para o jusfilósofo português, a "norma só poderá ter-se definitivamente por aplicável, ou só estará definida na sua acabada aplicabilidade, quando se verificar 'experimentalmente' (i.é, através do discurso metodológico de problematização valorada) a sua intencional-normativa adequação ao caso concreto". (NEVES, 1993, p. 167) Ainda consoante Castanheira Neves:

(...) em virtude de serem as normas prescritas na previsão apenas das hipóteses mais frequentes, comuns ou típicas dos casos que se propõem regular (...) não fica excluída a possibilidade de se decidir concretamente da sua aplicabilidade em termos diversos daqueles que imediatamente imporia o sentido significativo e conceitual (ou interpretável em abstracto) das normas, já aplicando-as a situações e casos formalmente abrangidos por ele. (NEVES, 1993, p. 171)

Destarte, uma vez verificado que da aplicação da regra resultará injustiça evidente, impõe-se ao operador resguardar o conteúdo valorativo do sistema, não aplicando a regra específica: como sustenta Juarez Freitas, não se trata de se propor oposição ao Direito, senão à lei injusta. (FREITAS, 1989, p. 14)

(E) Proteção da confiança legítima

A compreensão da ideia de proteção da confiança só se mostra possível a partir do paradigma da juridicidade: a proteção da confiança legitimamente depositada na Administração pressupõe uma contemporização da legalidade estrita e da chamada supremacia do interesse público, reinterpretando-se tais princípios topicamente à luz do sistema.

Destarte, expõe Maffini que a garantia da proteção da confiança tem por escopo "a conservação de condutas administrativas ou de seus efeitos, mesmo quando decorrentes de atuações contrárias à ordem jurídica e, com maior razão ainda, quando perpetradas validamente". (MAFFINI, 2005, p. 233) Significa dizer que a pessoa que confiou no ato emanado do Poder 
Revista da Faculdade de Direito da UERJ,V.2, n.22,jul./dez.2012

Pá g i n a | 21

Público poderá vislumbrar a possibilidade de ver o referido ato administrativo produzir efeitos ainda que possua vícios; outrossim, em sendo o ato formalmente perfeito, não poderá ser desfeito sem um mínimo de razoabilidade para tanto, uma vez que a confiança depositada no ato pelo cidadão é digna de tutela jurídica - tanto quanto as prerrogativas do Estado - enquanto corolário do princípio da segurança jurídica no tocante à manutenção do status jurídico.

Em consonância aos elementos já apontados, mostra-se adequada a interpretação segundo a qual a proteção da confiança deva ser alçada a nível constitucional, uma vez que, como exposto por Maffini (MAFFINI, 2005, p. 237) a proteção da confiança é dedução direta do princípio da segurança jurídica, o qual, por sua vez, é elemento configurador do Estado de Direito, demonstrando-se, pois, a relevância da tutela da confiança pelo sistema.

Desta forma, mostra-se necessária a superação do paradigma da legalidade, já que, como visto, a operacionalidade de diversos elementos jurídicos só se mostra possível a partir da análise ampla do sistema, configuradora e legitimadora da juridicidade.

\section{CONCLUSÕES}

Objetivou-se demonstrar que o surgimento da ideia de legalidade, associada a um determinado contex to histórico, correspondente ao do Estado Liberal, trouxe uma série de noções de conteúdo positivo para o Direito, aprimorando a compreensão do Estado, cujo poder, limitado e legitimado, passou a ser exercido de modo não-absoluto.

Todavia, o avanço científico do Direito, associado à necessária interpretação sistemática de seu conteúdo, tornou insuficiente a teoria consubstanciada no princípio da legalidade. Assim, uma vez compreendido o fenômeno jurídico como sistêmico, restaram afastados os métodos silogísticos de aplicação e interpretação adotados outrora.

Desta forma, a juridicidade, compreendida como ideia de observância e respeito à totalidade do sistema normativo, integrado por regras, princípios e valores, axiologicamente hierarquizáveis e teleologicamente aplicáveis, superou a noção de legalidade estrita, porquanto esta última não se coaduna à complexidade social e jurídica contemporâneas.

Destarte, novas possibilidades jurídicas despontam no cenário normativo, viabilizando-se a flexibilização/adaptação de institutos jurídicos à luz dos elementos que passaram a ser reconhecidos com força normativa própria e autônoma, com especial destaque aos princípios 
Revista da Faculdade de Direito da UERJ,V.2, n.22,jul./dez.2012

Pá g in a | 22

constitucionais. Trata-se não da perda da racionalidade formal, mas sim da assunção de uma nova racionalidade, comprometida com a materialidade possível do Direito.

Em síntese, a adequada apreensão do fenômeno da juridicidade representa a superação da legalidade estrita, em virtude da sistematicidade hodiernamente atribuída ao arcabouço normativo e à efetiva valorização da principiologia constitucional.

\section{REFERÊNCIAS BIBLIOGRÁFICAS}

ALBUQUERQUE JÚNIOR, Raimundo Parente. Juridicidade contra legem no processo administrativo: limites e possibilidades à luz dos postulados da razoabilidade e da proporcionalidade. Porto Alegre: Livraria do Advogado, 2010.

ARONNE, Ricardo. Por uma nova hermenêutica dos direitos reais limitados. Rio de Janeiro: Renovar, 2001.

Razão \& caos no discurso jurídico. Porto Alegre: Livraria do Advogado, 2010.

ATIENZA, Manuel. As Razões do Direito: teorias da argumentação jurídica. São Paulo: Landy Editora, 2006.

ÁVILA, Humberto. Teoria dos princípios - da definição à aplicação dos princípios jurídicos. São Pulo: Malheiros, 2009.

BANDEIRA DE MELLO, Celso Antônio. Curso de direito administrativo. São Paulo: Malheiros, 2005.

BARROSO, Luís Roberto. Neoconstitucionalismo e Constitucionalização do Direito: O Triunfo

Tardio do Direito Constitucional no Brasil. Revista Eletrônica sobre a Reforma do Estado (RERE), Salvador, Instituto Brasileiro de Direito Público, n. 9, março/abril/maio, 2007.

Interpretação e aplicação da Constituição. São Paulo: Saraiva, 2010. 
BESTANE, Bernadete. Bernardo de Souza - a palavra como instrumento de justiça. Contgraf: Porto Alegre, 2009.

BINENBOJM, Gustavo. Uma Teoria do Direito Administrativo. Rio de Janeiro: Renovar, 2008.

BUEno, J. A. Pimenta. Direito Público Brasileiro e Análise da Constituição do Império. Brasília: Ministério da Justiça e Senado Federal/UnB, 1978.

CANARIS, Claus-Wilhelm. Pensamento sistemático e conceito de sistema na ciência do direito. Lisboa: Fundação Calouste Gulbenkian, 2008.

CANOTILHO, J.J. Gomes. Direito constitucional e teoria da constituição. Coimbra: Almedina, 2003.

COSTA, Gerson Godinho da. Justificação democrática da atividade jurisdicional: o contributo da lógica jurídica de Chaïm Perelman. Porto Alegre: PUCRS, 2008.

CRETELLA JÚNIOR, José. Curso de direito administrativo. Rio de Janeiro: Forense, 2000.

DI PIETRO, Maria Sylvia Zanella. Direito administrativo. São Paulo: Atlas, 2007.

FERREIRA FILHO, Manoel Gonçalves. Estado de Direito e Constituição. São Paulo: Saraiva, 2007.

FIGUEIREDO, Lúcia Valle. Curso de Direito Administrativo. São Paulo: Malheiros, 2003.

FREITAS, Juarez. A substancial inconstitucionalidade de lei injusta. Petrópolis: Vozes, 1989.

A interpretação sistemática do direito. São Paulo: Malheiros, 2004.

O controle dos atos administrativos e os princípios fundamentais. São Paulo: Malheiros, 2009. 
GRAU, Eros Roberto. Ensaio e discurso sobre a interpretação/aplicação do direito. São Paulo: Malheiros, 2006.

HART, Herbert L.A. O conceito de direito $-5^{a}$ ed. Lisboa: Fundação Calouste Gulbenkian, 2007.

MAFFINI, Rafael da Cás. Princípio da proteção substancial da confiança no Direito Administrativo brasileiro. Porto Alegre: UFRGS, 2005.

MONTESQUIEU. O Espírito das Leis. São Paulo: Saraiva, 2004.

MOREIRA NETO, Diogo de Figueiredo. Juridicidade, pluralidade normativa, democracia e controle social. In: ÁVILA, Humberto. Fundamentos do Estado de Direito. São Paulo: Malheiros, 2005.

NEVES, A. Castanheira. Metodologia jurídica. Coimbra: Coimbra Editora, 1993.

OTERO, Paulo. Legalidade e Administração Pública: o sentido da vinculação administrativa à juridicidade. Coimbra: Almedina, 2011.

PASTOR, Juan Alfonso Santamaría. Principios de Derecho Administrativo. Madrid: Editorial Centro de Estudios Ramón Areces, 2000.

PERELMAN, Chaïm. Lógica jurídica. São Paulo: Martins Fontes, 2004.

RODRIGUES, Itiberê de Oliveira. Fundamentos dogmático-jurídicos da história do princípio da legalidade administrativa no Brasil. In: ÁVILA, Humberto. Fundamentos do Estado de Direito. São Paulo: Malheiros, 2005.

SILVA, José Afonso. Comentário contextual à Constituição. São Paulo: Malheiros, 2009.

SILVA, Ovídio Baptista da. Processo e Ideologia: o paradigma racionalista. Rio de Janeiro: Forense, 2006. 
Revista da Faculdade de Direito da UERJ,V.2, n.22,jul./dez.2012

Pág in a | 25

SÖHNGEN, Clarice Beatriz da Costa. Hermenêutica e lingüística. Disponível em <http://bit.ly/8XyWhM>, 2006.

SOUZA JUNIOR, Cezar Saldanha. Consenso e tipos de Estado no Ocidente. Porto Alegre:

Sagra Luzzatto, 2002. 